\title{
Samuel J. Fomon - Champion of Growth
}

\author{
Ekhard E. Ziegler Ferdinand Haschke
}

A career-long preoccupation with growth is what sets Samuel J. Fomon apart from most other nutrition scientists. Not to belittle his many other contributions, but the elucidation of childhood body composition and its changes and the introduction of growth as an indicator of nutritional adequacy stand out as his most distinct and arguably most important contributions. Had he done nothing else, his place in the pantheon of nutrition science would be secure. He did, of course, do much else.

Samuel J. Fomon died on December 18, 2007, after a valiantly fought drawn-out battle with multiple myeloma. He was born on March 9, 1923, in Chicago. After the early death of his mother he spent his childhood with relatives in Wisconsin where he also attended high school. In 1944 he graduated cum laude from Harvard and in 1947 received his medical degree from the University of Pennsylvania. After residency training in pediatrics at the Children's Hospital of Philadelphia he completed a fellowship in renal physiology at the Children's Hospital of Cincinnati. He served as captain with the US Army for two years before joining the Department of Pediatrics at the University of Iowa in 1954. Although he became Professor Emeritus in 1993 he continued to be quite active in research for another decade. The many important positions he held included the Chairmanship of the Committee on Nutrition of the American Academy of Pediatrics (1960-63), Councilor, Editorial Board Member and eventually President (1981-82) of the American Society of Clinical Nutrition, and Editorial Board Member, Councilor and eventually President of the American Institute of Nutrition. Of the many honors bestowed on him, the Bristol-Meyers Squibb/Mead Johnson Award (1992) was probably the most prestigious. He attracted dozens of fel-

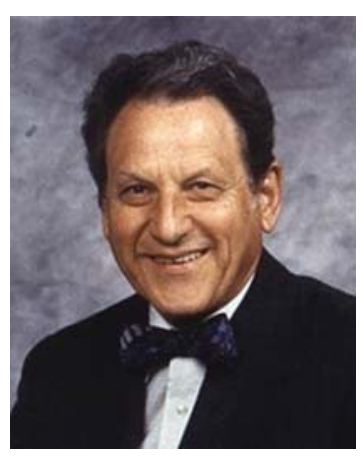

lows and post-doctorates from all over the world and trained many doctoral students. Most left changed, some more, some less, but all left carrying an implant, a compass to sound infant nutrition.

Not long after he arrived at Iowa, Dr. Fomon was asked to take over leadership of the metabolic unit that had been in existence since the 1920s. Thus began a five-decadelong journey through childhood nutrition. When he was finished, he had changed the field for good. He spent the first years at Iowa conducting metabolic balance studies with an eye on determining nutrient requirements of infants. Realizing that balance studies are poorly suited for the purpose, and appreciating that growth is the driving force behind the young child's high nutritional needs, he began to devote a good portion of his energy to the study of growth and made seminal contributions in two areas. First came body composition. In a burst of creative energy he constructed from limited data a first draft of what would become the reference infant. Immediately the model was put to use for deriving the nutrient require-

\begin{tabular}{|c|c|}
\hline KARGER & $\begin{array}{l}\text { (c) } 2008 \text { Nestec Ltd., Vevey/S. Karger AG, Basel } \\
0517-8606 / 07 / 0653-0093 \$ 23.50 / 0\end{array}$ \\
\hline Fax +41613061234 & \\
\hline $\begin{array}{l}\text { E-Mail karger@karger.ch } \\
\text { www.karger.com }\end{array}$ & $\begin{array}{l}\text { Accessible online at: } \\
\text { www.karger.com/ane }\end{array}$ \\
\hline
\end{tabular}


ments by the factorial method, another important creation with far-reaching consequences. Next came the development and application of methods for the accurate and reproducible measurement of growth. With these methods it became possible, among other things, to use growth as an indicator of nutritional adequacy. It is fair to say that the introduction of standardized measurements of growth played an important role in the emancipation of infant nutrition from a qualitative to a quantitative field of inquiry.

The body composition work began from a base of very limited information, which consisted of data from chemical analyses of stillborn infants and a handful of adult subjects as well as total body water data and tissue composition data. In 1966 the first version of the male reference infant was presented [1]. It was quickly followed by a major revision based on new data [2]. This, the 1967 male reference infant, has stood the test of time. It enabled the estimation of requirements for protein and other nutrients by the factorial method. Just as important were the insights it provided, such as that as much as one half of the protein taken during the first few months of life goes to growth, or that $40 \%$ of the infant's weight gain is fat, which explains why the energy intakes of infants are so exceedingly high. The factorial method has lived on and continues to fertilize other fields, such as nutrition of premature infants $[3,4]$.

In the years that followed, data on total body potassium as well as on bone mineral content became available. With this new information a 9-year-old reference boy was constructed [5]. The new information also led to an overhaul of the reference infant and extension all the way to age 10 years (reference children), this time for girls as well as for boys [6]. An important insight from this work was that the density of the fat-free body mass of children is appreciably lower than that of adults. This had important implications for the determination of body fat by methods such as hydrodensitometry and plethysmography, which rely on assumptions regarding the density of fatfree body mass. Body composition continued to occupy Dr. Fomon and as late as 2002 he summarized his life's work in the area [7].

To obtain reproducible growth measurements and enhance the interpretability of growth data, Dr. Fomon insisted on meticulous attention to measurement techniques and, more importantly, on the use of rigorously standardized age intervals. He also emphasized the use of incremental data rather than achieved weight or height as the best way to analyze and interpret growth data. Standardized growth measurements began to be used in the mid 1960s [e.g., 8] and went on to be used with great success to answer important questions, such as what the effect of formula concentration is on the growth of normal infants [9] and many more. The improved measurement methods thus permitted the use of growth as an outcome in nutritional studies and greatly expanded the range of questions that could be answered with simple, well-conducted growth studies.

In 1988 the US Food and Drug Administration sought advice from the American Academy of Pediatrics on the clinical testing of infant formulas. The response of the Academy was prepared by Dr. Fomon. It recommended, among other measures, standardized growth studies as the ultimate test of the nutritional suitability of infant formulas. The FDA adopted the recommendations in their entirety and to this day follows the rules laid out in 1988 by Dr. Fomon.

Growth is not the only area where the creative energy of Dr. Fomon left an indelible imprint. But in terms of overall innovation and sheer impact, his work on growth stands out as his singular most important achievement.

\section{References}

1 Fomon SJ: Body composition of the infant. Part I: The male 'reference infant'; in Falkner F (ed): Human Development. Philadelphia, Saunders, 1966, pp 239-246.

2 Fomon SJ: Body composition of the male reference infant during the first year of life. Pediatrics 1967;40:863-870.

3 Fomon SJ, Ziegler EE, Vazquez HD: Human milk and the small premature infant. Am J Dis Child 1977;131:463-467.
4 Ziegler EE: Protein requirements of very low birth weight infants. J Pediatr Gastroenterol Nutr 2007;45:S170-S174.

5 Haschke F, Fomon SJ, Ziegler EE: Body composition of a nine-year-old reference boy. $\mathrm{Pe}$ diatr Res 1981;15:847-849.

6 Fomon SJ, Haschke F, Ziegler EE, et al: Body composition of reference children from birth to age 10 years. Am J Clin Nutr 1982;35: $1169-1175$.
7 Fomon SJ, Nelson SE: Body composition of the male and female reference infants. Annu Rev Nutr 2002;22:1-17

8 Fomon SJ, Younoszai, MK, Thomas, LN: Influence of vitamin $\mathrm{D}$ on linear growth of normal full-term infants. J Nutr 1966;88: 345-350

9 Fomon SJ, Filer LJ Jr, Thomas LN, Rogers RR, Proksch AM: Relationship between formula concentration and rate of growth of normal infants. J Nutr 1969;98:241-254. 